
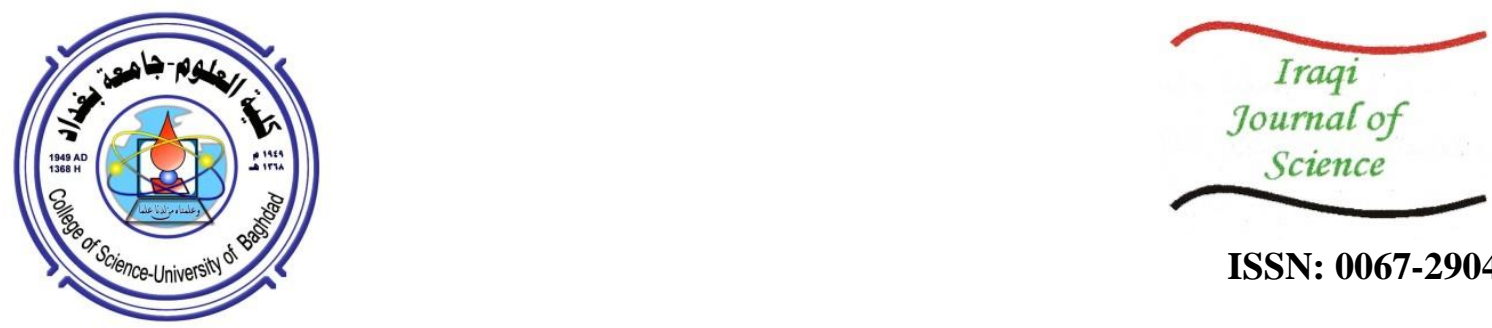

ISSN: 0067-2904

\title{
An Investigation of Seismic Velocity Variation through a Tectonic Boundaries-Case Study in Central Iraq
}

\author{
Ahmed S. AL-Banna*, Hassan E. Al-Assady \\ Department of Geology, College of Science, University of Baghdad, Baghdad, Iraq
}

Received: $13 / 9 / 2020$

Accepted: 10/2/2021

\begin{abstract}
A 3D velocity model was created by using stacking velocity of 9 seismic lines and average velocity of 6 wells drilled in Iraq. The model was achieved by creating a time model to 25 surfaces with an interval time between each two successive surfaces of about $100 \mathrm{msec}$. The summation time of all surfaces reached about 2400 msec, that was adopted according to West Kifl-1 well, which penetrated to a depth of $6000 \mathrm{~m}$, representing the deepest well in the study area. The seismic lines and well data were converted to build a 3D cube time model and the velocity was spread on the model. The seismic inversion modeling of the elastic properties of the horizon and well data was applied to achieve a corrected velocity cube. Then, the velocity cube was converted to a time model and, finally, a corrected 3D depth model was obtained. This model shows that the western side of the study area, which is a part of the stable shelf, is characterized by relatively low thickness and high velocity layers. While the eastern side of the study area, which is a part of the Mesopotamian, is characterized by high thickness and low velocity of the Cretaceous succession. The Abu Jir fault is considered as a boundary between the stable and unstable shelves in Iraq, situated at the extreme west part of the study area. The area of relatively high velocity gradient is considered as the limit of the western side of the Mesopotamian basin. This area extends from Najaf-Karbala axis in the west to the Euphrates River in the east. It is found that the 3D stacking velocity model can be used to obtain good results concerning the tectonic boundary.
\end{abstract}

Keywords: 3d seismic model, Stacking velocity, Seismic inversion, Tectonic boundary, Central Iraq.

استخدام الموديل الثلاثي الابعاد للسرع المتراصة لتحديد الحدود التكتونية الرئيسة في وسط العرلق

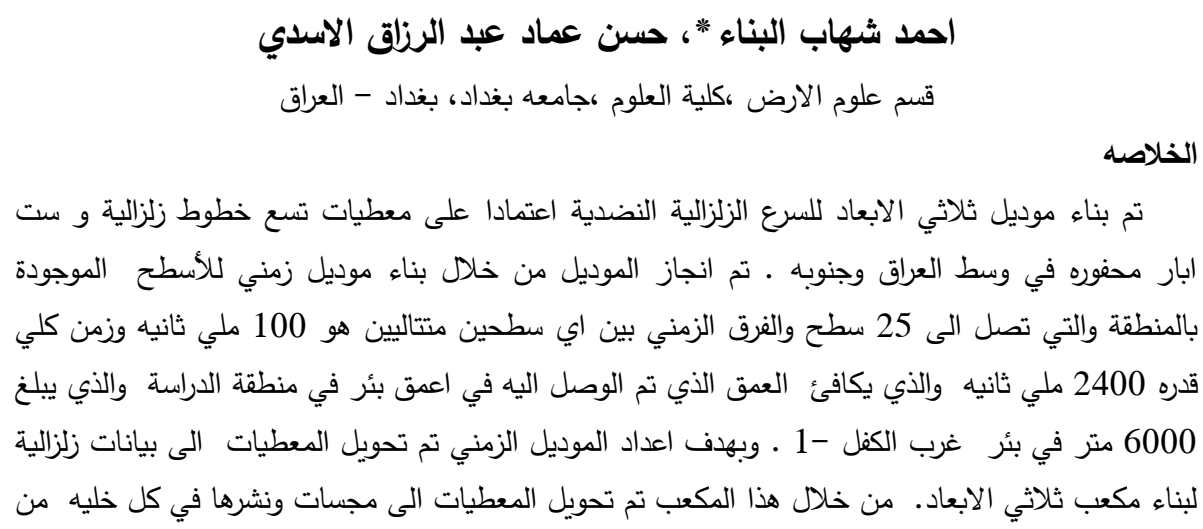




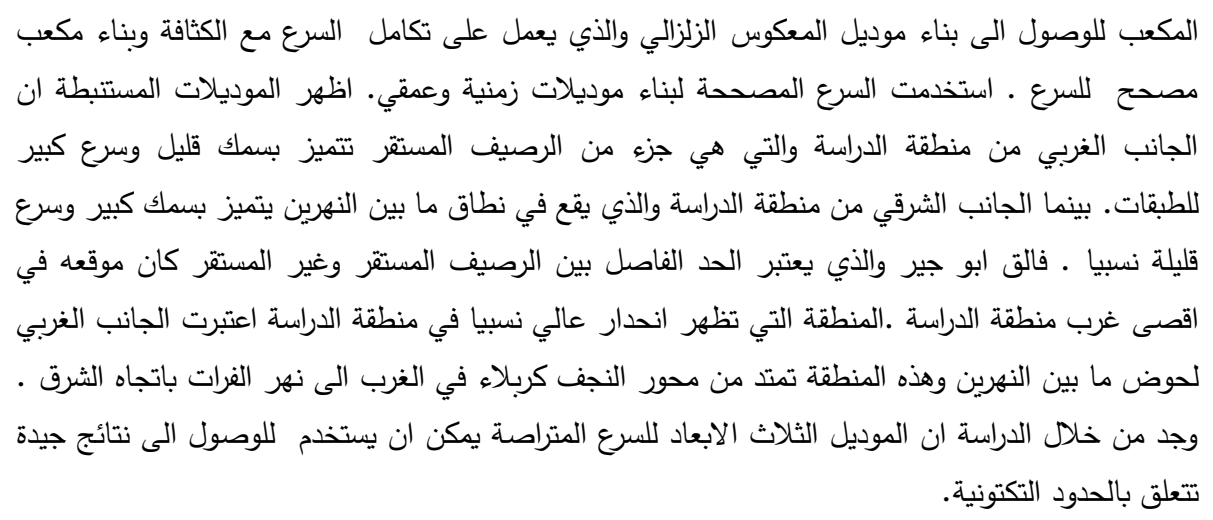

\section{Introduction}

The seismic reflection method is used to investigate subsurface depending on recording and analyzing the seismic responses of waves reflected from rock interfaces that have relatively perceptible differences in velocities and densities [1]. This method relies on the differences in the velocity of propagated seismic elastic wave through different geological or man-made materials. The primary objective of the geophysical interpretation is usually to provide contour maps that show the depth of a series of reflectors which have been picked on the seismic sections [2]. The velocity model is a tool that aims to overflow the uncertainty in interpretation and integrate the available seismic measurements into a modeling workflow [3,4]. The velocity model is usually built for several purposes, including depth conversion accurately estimating geologically important seismic events, such as fractures, faults, and unconformities, and identifying structural closures for better hydrocarbon targeting $[5,6]$.

Lower Cretaceous reservoir rocks represent 30\% of Iraq's hydrocarbon reserves [7]. Yamama, Nahr Umar, and Zubair formations (Lower Cretaceous) are carbonate and clastic successions that deposit in the Mesopotamian and eastern flank of the Arabian platform [8].

The seismic velocity, as a diagnostic petrophysical property, is used to improve and develop many oil fields in Iraq. Kifl, west Kifl, and Merjan oil fields in the Stable Shelf, as well as Ahdab and Dhafriyah oil fields in the Unstable Shelf, were considered in the present study. These oil fields were selected to compare the velocity root mean square (RMS) values required to process the seismic lines and the change of velocity in wells in two different tectonic units (Stable and Unstable Shelves in Iraq) in order to investigate the change in velocity and enhance the quality of interpretation.

\section{Description of the study area}

The study area is located on two different tectonic zones; these are the Stable Shelf and Unstable Shelf tectonic zones. The Stable Shelf zone contains Kifl, west Kifl, and Merjan oil fields in the southwest of Baghdad. The area lies in the middle of Iraq between Najaf and Karbala governorates (west of the Euphrates River), as shown in the Figure-1 [9]. The Unstable Shelf zone, including Dhafriyah and Ahdab oil fields, lies within the administrative boundaries of Wasit province where the city of Kut is situated in the center of the region. The Tigris River passes in the middle of the study area. To the south of the study area, Ahdeb field is located where the whole area is covered by irrigation and drainage and alluvium deposits, which consist of clay, sand, and sediments of marshes and swamps, which are abundant. Dhafriah field consists of two domes, one is located at the north and the other in the south. The structural axis of these fields trends NW - SE.

The Dufriah and Ahdab oil fields are located in the Mesopotamian zone in the unstable tectonic zone. The_Kifl, west Kifl, and Merjan oil fields are located in Salman- Rutbah zones of the Stable Shelf tectonic unit [10] and within the transition zone between the stable and unstable zones (the inner and outer platform) in the western part of Iraq [11]. The general trend of the transversal fault systems (Rahimawi, Hilla, Shbicha, and Najaf) is NE - SW and they appear on the surface. The transversal fault systems were formed during the Latest Precambrian by Nabitah orogeny and re-activated repeatedly during the Phanerozoic. The study area is located, according to the Najd fault system, between Tikrit-Amara and Euphrates Boundaries, while according to the Transversal Fault System; it lies between Takhadid-Qurna and Kut-Dezful $[12,13]$. According to Fouad (2013), the involved area is located within the inner Platform and the outer Platform of the Arabian Plate [14]. The rate of 
tectonic movement is $0.2-2.5 \mathrm{~cm} / 100$ year as up-lifting [15]. About three longitudinal and other three transvers faults cross the study area [16].

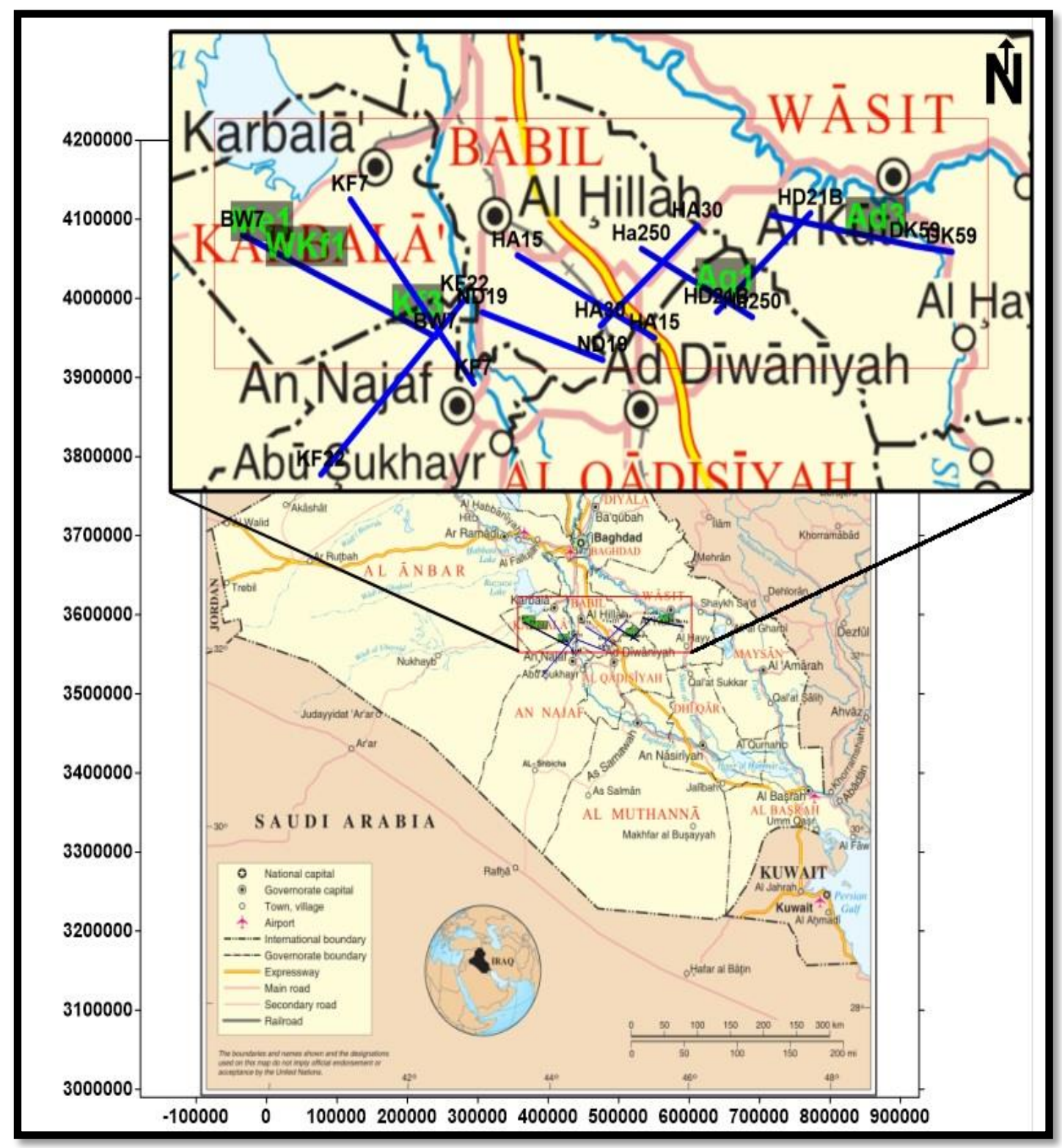

Figure1- The location map of the study area [9]. 


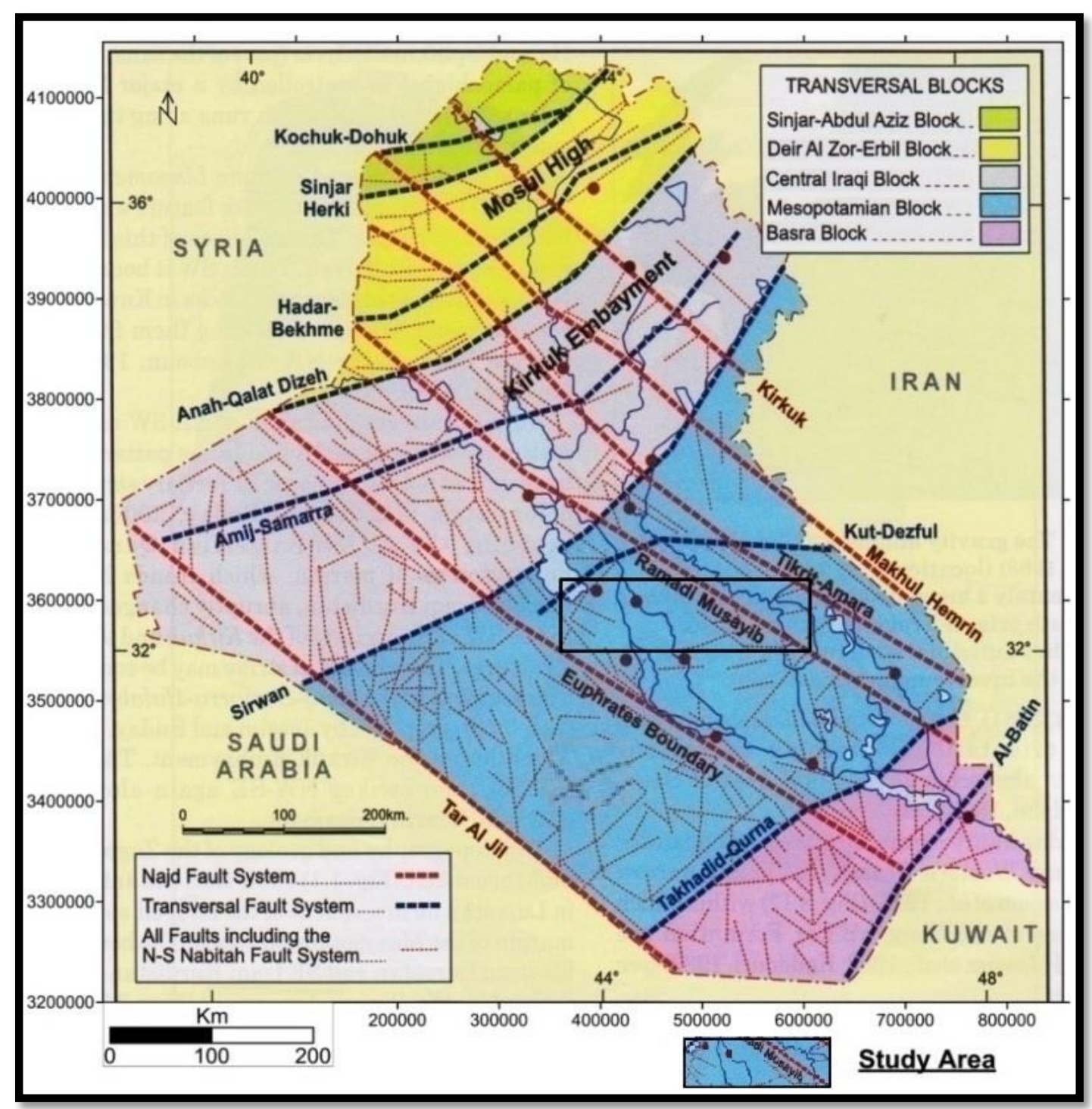

Figure 2- Transversal blocks and fault systems of the study area [13].

\section{The available data}

Three type of data were used in the current study; first,

1- Well data: including well tops, total depths, Rotary Table Kelly Bushing (RTKB), and the coordinates of the five wells in the study area.

2- Six seismic check-shots for the wells, which are Kifl-1, West Kifl-1, Merjan-1, Afaq-1, Ahdab-1, and Dhufriah-1.

3- Nine seismic lines that cover most parts of the study area; these are Baghdad West-7 (BW-7), Diyala- Kut -95 (DK-59), Hashmiyah-250 (HA-250), Hilla-Diwaniya 21-B (HD 21-B), Hashmiyah-15 (HA-15), Hashmiyah-30 (HA-30), Kifl-22 (KF-22), Kfil-7 (KF-7), and Najaf-Diwaniya-19 (ND-19).

\section{The procedure of work}

The processing method included many steps, which were: 1- loading the available data, such as well tops and total depth of the considered wells Kifl1(Kf1), West Kifl1(WKf1), Merjan1(Me1), Afaq1(Aq1), and Ahdab1(Ad1), on MS Excel program and exporting them as a space delimited extension (.prn) to be suitable to the next processing step (Figure- 3). 2- The Two Way Time (TWT) of 25 surfaces was selected, with an interval time between each two successive surfaces of 100 msec. The total considered time for the 25 surfaces is $2400 \mathrm{msec}$, which is equivalent to a depth of about $6000 \mathrm{~m}$ (Figure-4). 


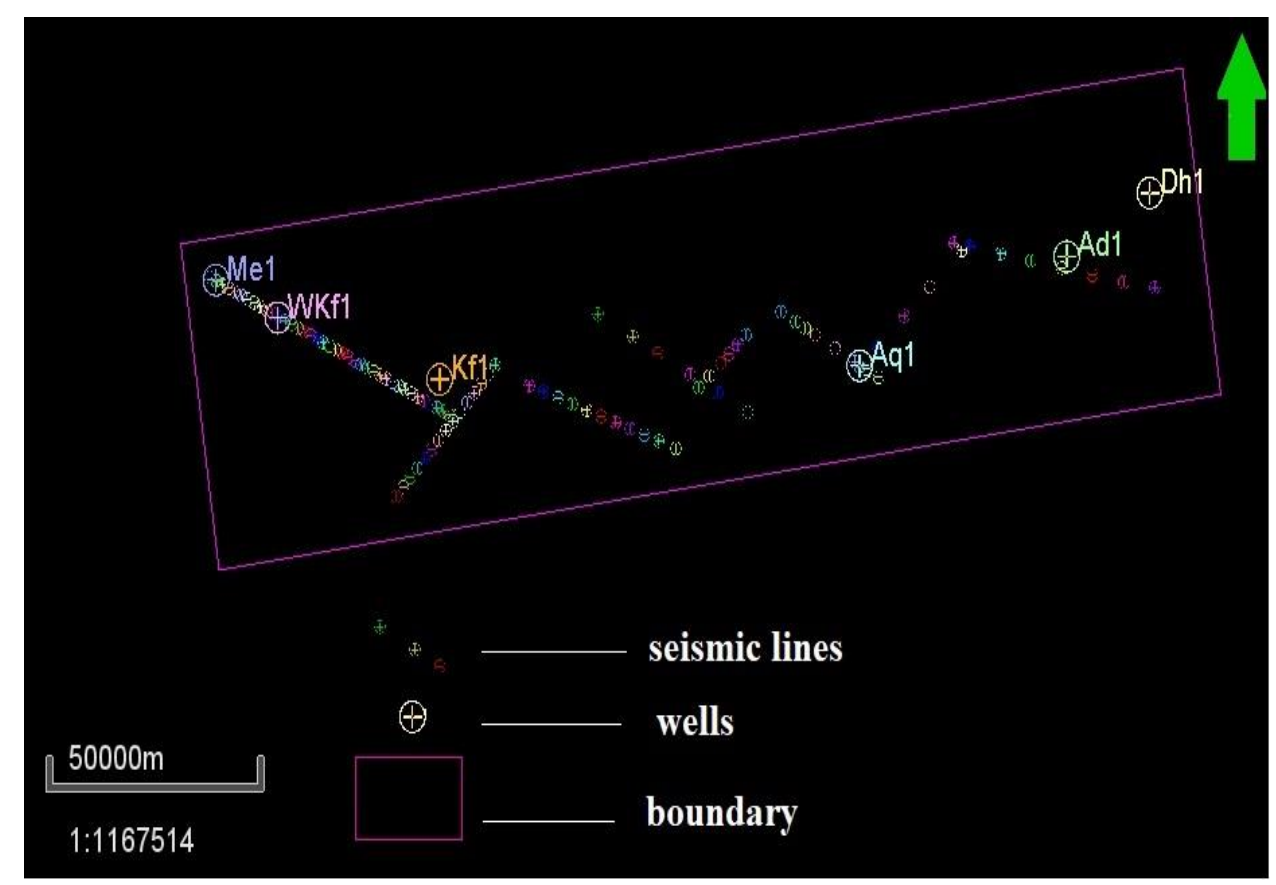

Figure 3- The loading of wells and seismic lines within the boundary.

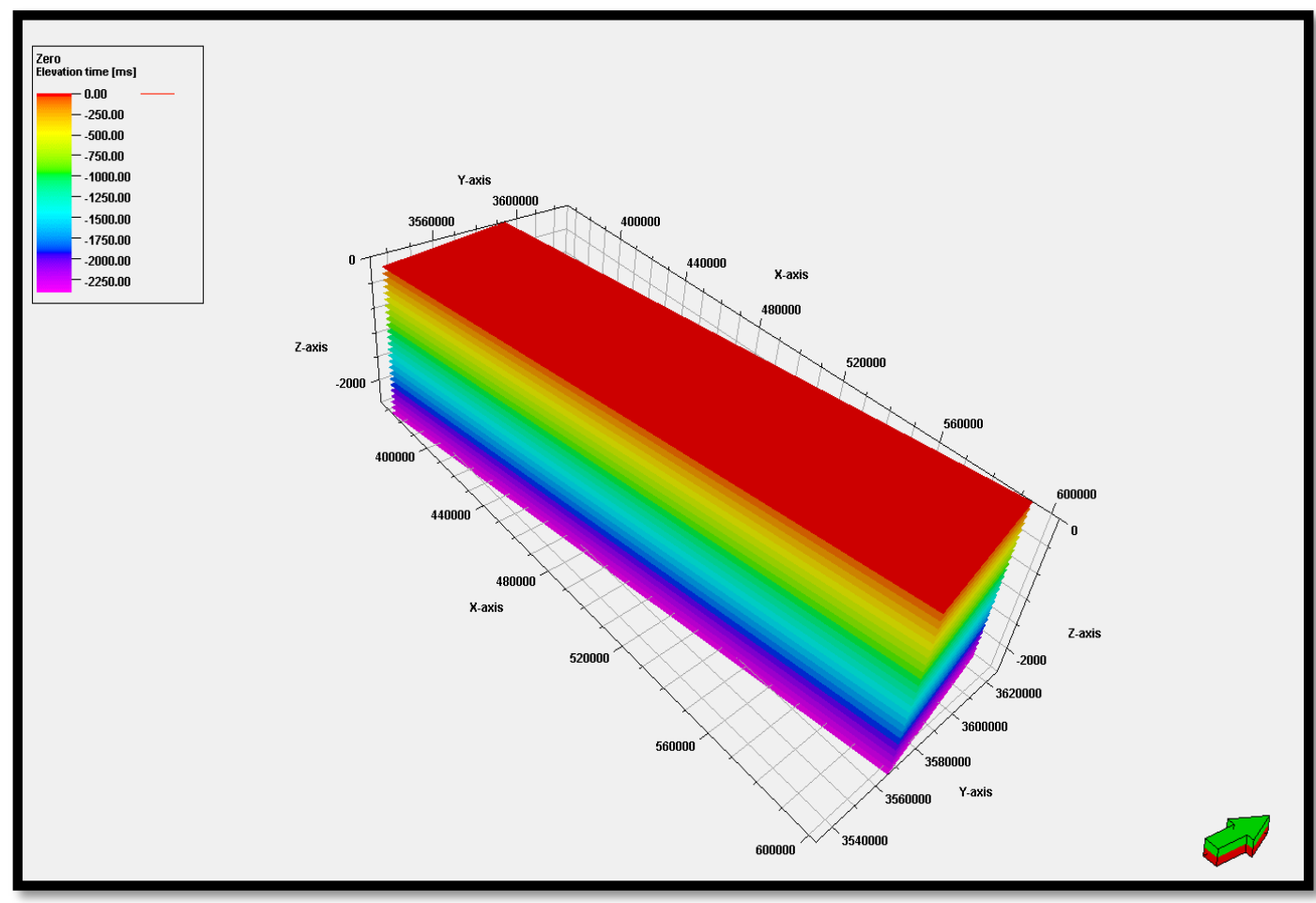

Figure 4- The 3D model of 25 considered TWT surfaces.

\section{The flow chart of the interpretation steps}

The seismic interpretation was performed by using special applications, using interactive software (petrel from schlumberger, 2016) with the interpreter to obtain faster and more accurate interpretation processes. The main steps of the interpretation process used in the current study were represented by a flow chart, including the following steps (Figure-5):

1- Inserting available well information, including check-shot, RMS velocity of seismic lines, and well tops. 
2- Converting well data to logs.

3- Converting the logs into a 3D seismic cube to prepare the time model.

4- Integrating the velocities by seismic inversion, which generates a new model called the inversion property builder (IPB).

5- Generating a velocity model and drawing maps to show the behavior and variation of interval, average, and stacking velocities and comparing the results with each other.

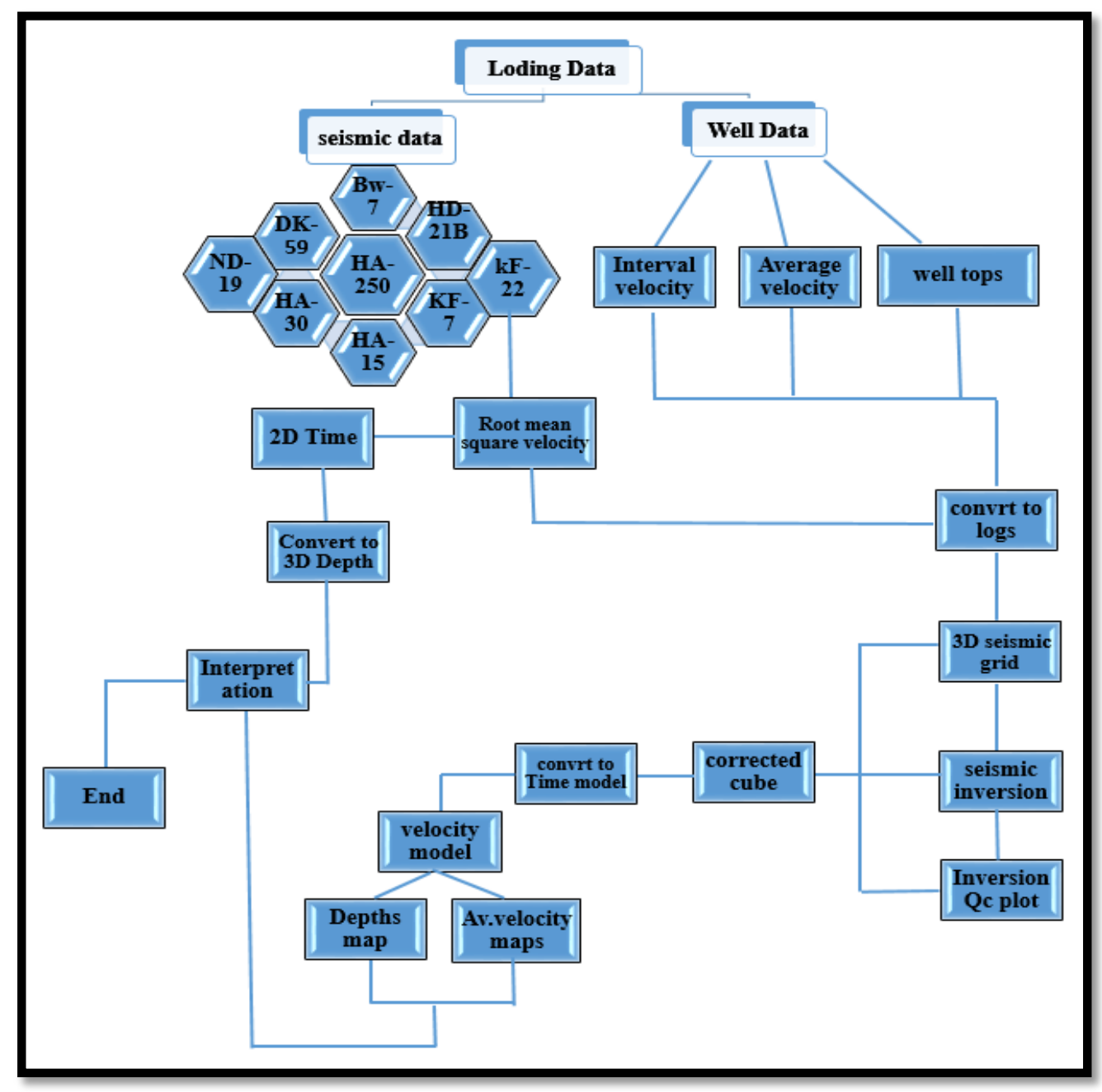

Figure 5- A flowchart that illustrates the main steps of the current seismic interpretation study.

\section{Results and Discussion \\ The velocity model}

The root mean square of the velocity (Vrms) and the average velocity (Vavg) values were spread on the study area to convert them to logs velocity data and to build the model. The well upscaling tool acts to scale-up well logs in an automatic process with some user settings available. For each grid cell, all $\log$ values that fall within the cell will be averaged according to the selected algorithm to produce one log value for that cell. The resulting 3D grid will only hold values for the $3 \mathrm{D}$ grid cells that the wells have penetrated. Hence, to spread the logs in the model, all zones (25) will be spread in this model by the Gaussian method as normal distribution (Figures- 6 and 7). It is shown that the velocity in this model spreads randomly. 


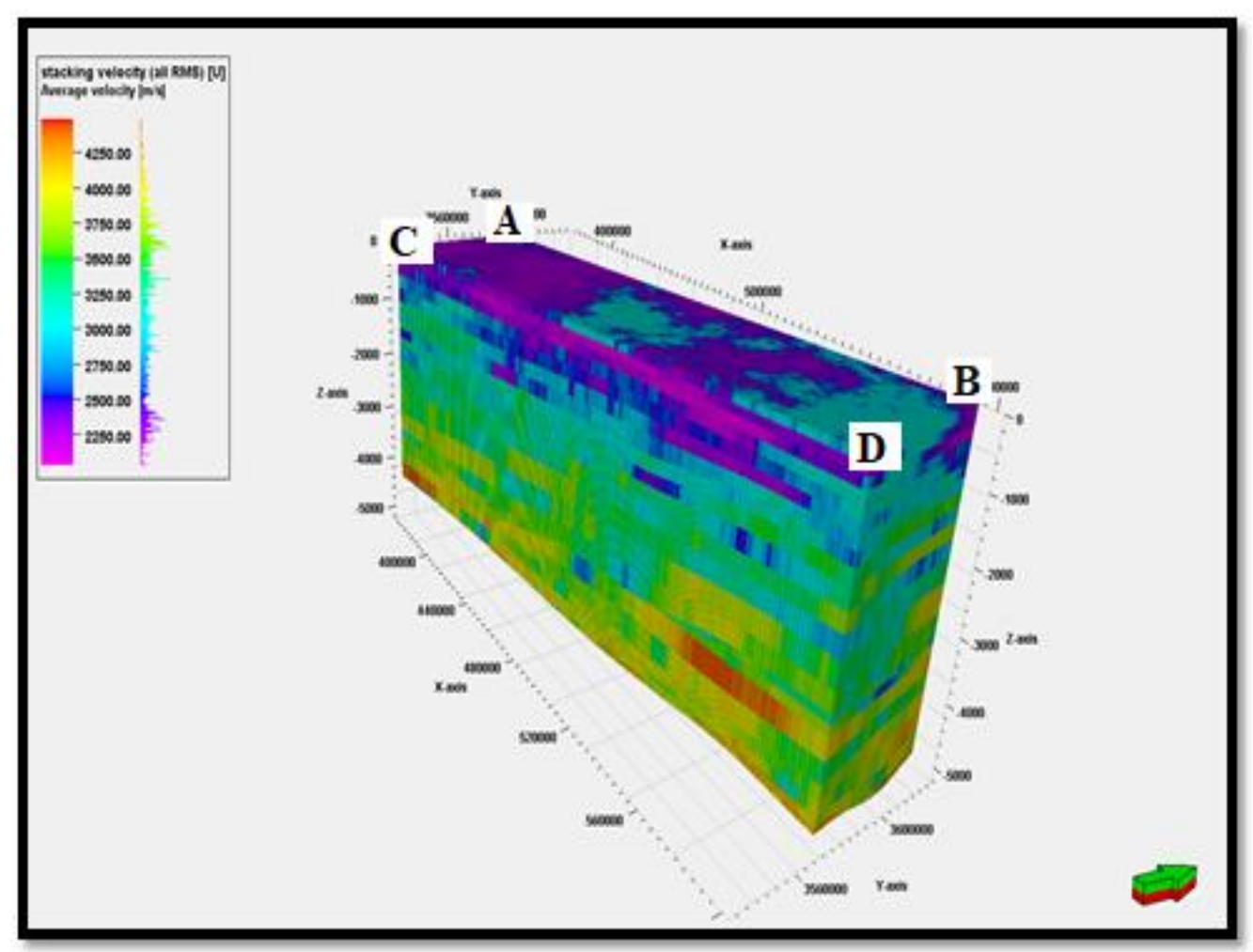

Figure 6- The time model of RMS velocity logs (from seismic lines).

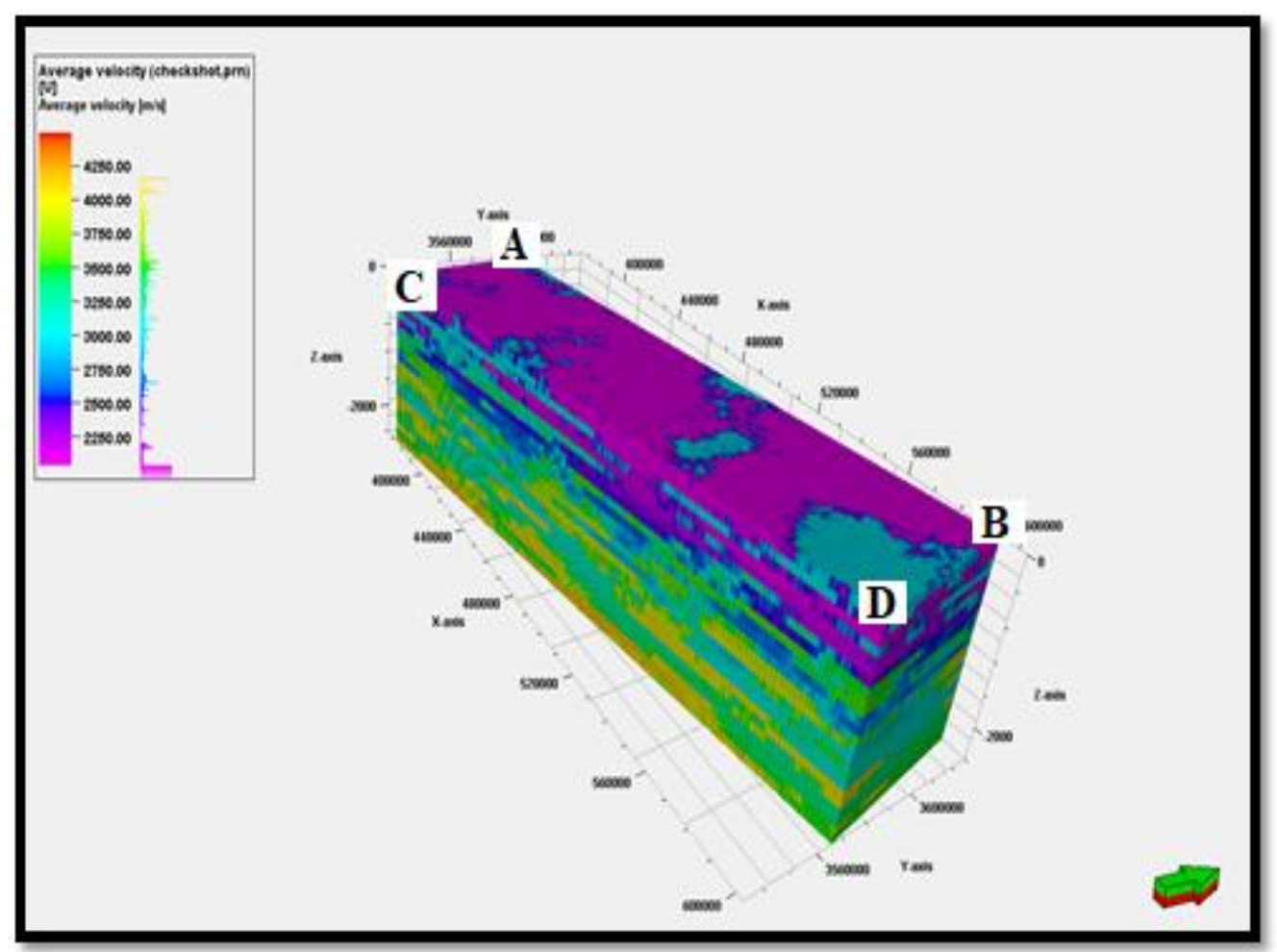

Figure 7- The new time model of average velocity logs from (check-shot).

\section{The integration between two velocities (RMS and AVG)}

Each velocity has its parameters and, hence, to make an integration, a seismic inversion must be performed by transferring seismic velocity data to seismic data (Figures- 8 and 9). 


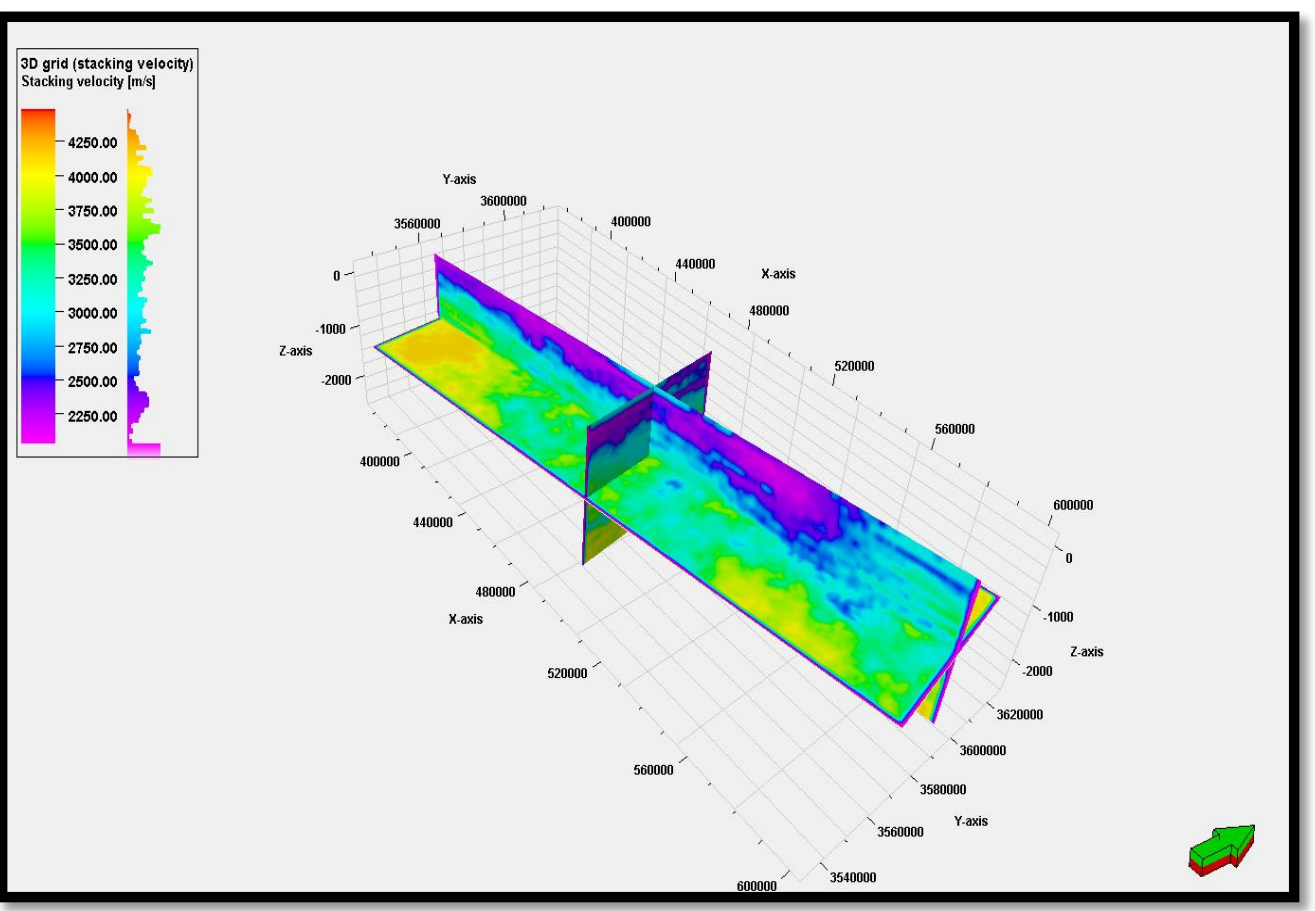

Figure 8- The 3D grid seismic cube for the converted stacking velocity model.

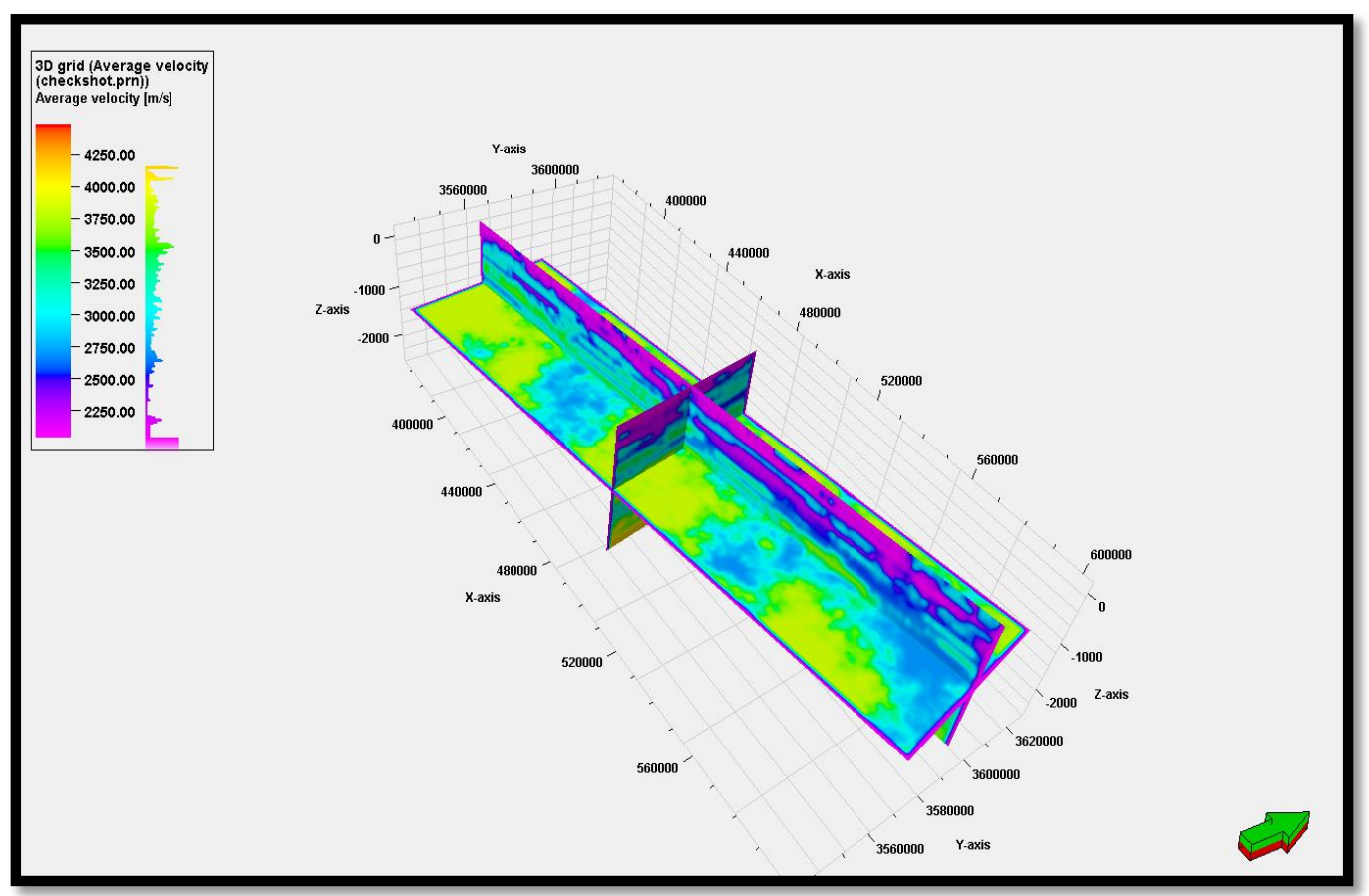

Figure 9- The 3D grid seismic cube for the converted average velocity model.

\section{The seismic inversion}

The inversion property builder (IPB) was employed for the modeling of the elastic properties of and horizons and well data.

This step is the entrance into the process of correction or compatibility between the Vrms data from the seismic line and the average velocity values from the check-shot. For this purpose, a new cube was created, that includes a 3D grid seismic cube of stacking velocity of RMS and logs of average velocity from the check-shot and the 6 wells that have been loaded before. The new cube is called the IPBcorrected stacking velocity (Figure-10). 


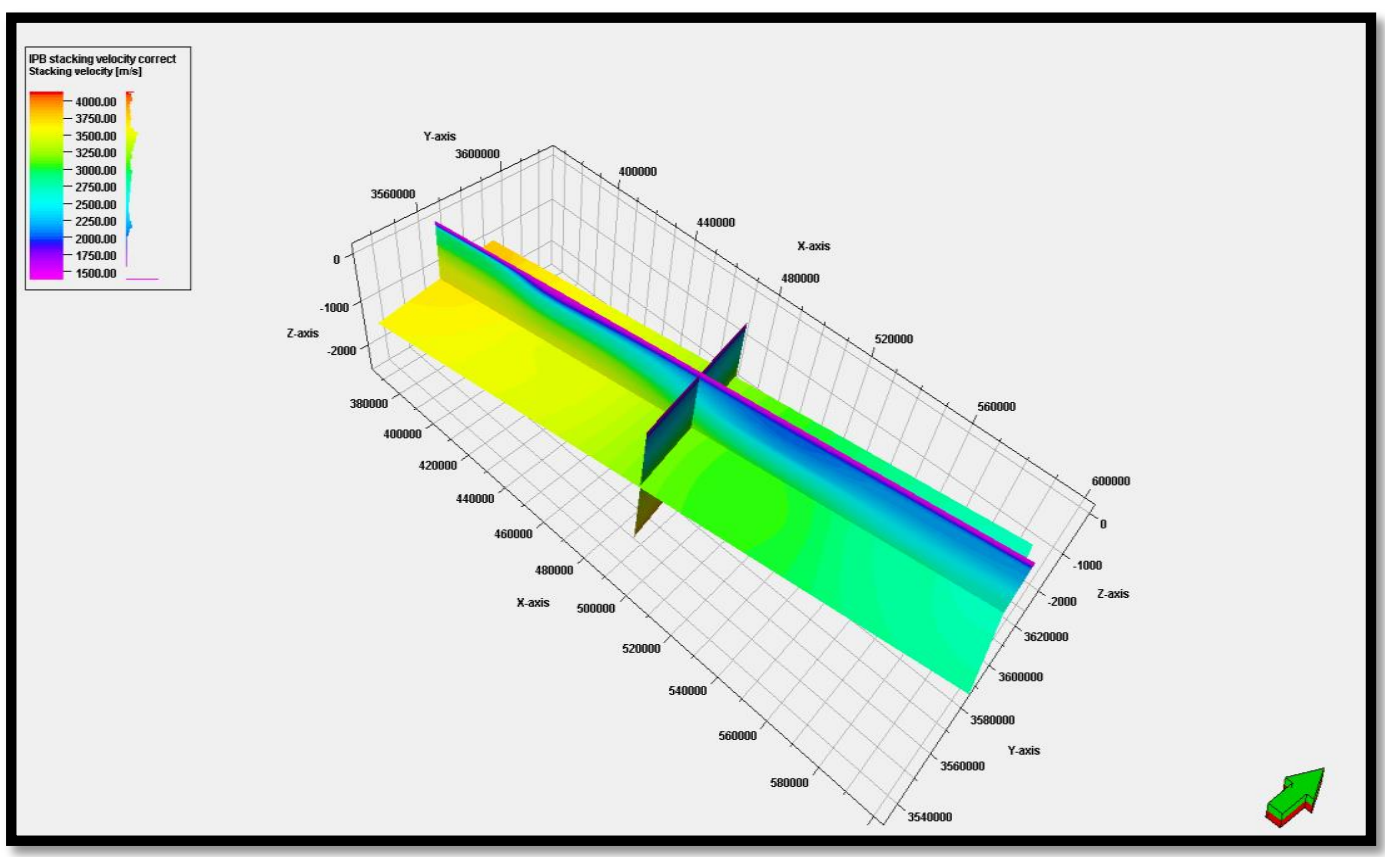

Figure 10- The new IPB stacking velocity corrected to seismic cube for the study area.

\section{The inversion QC plot}

This property acts on drawing the results of seismic inversion (IPB stacking velocity corrected seismic cube) with average logs of the check-shot and the 6 wells with TWT surfaces (Figure- 10). The QC inversion for the corrected and non-corrected stacking velocity values (All RMS) was performed and the differences were compared (Figures- 11 and 12).

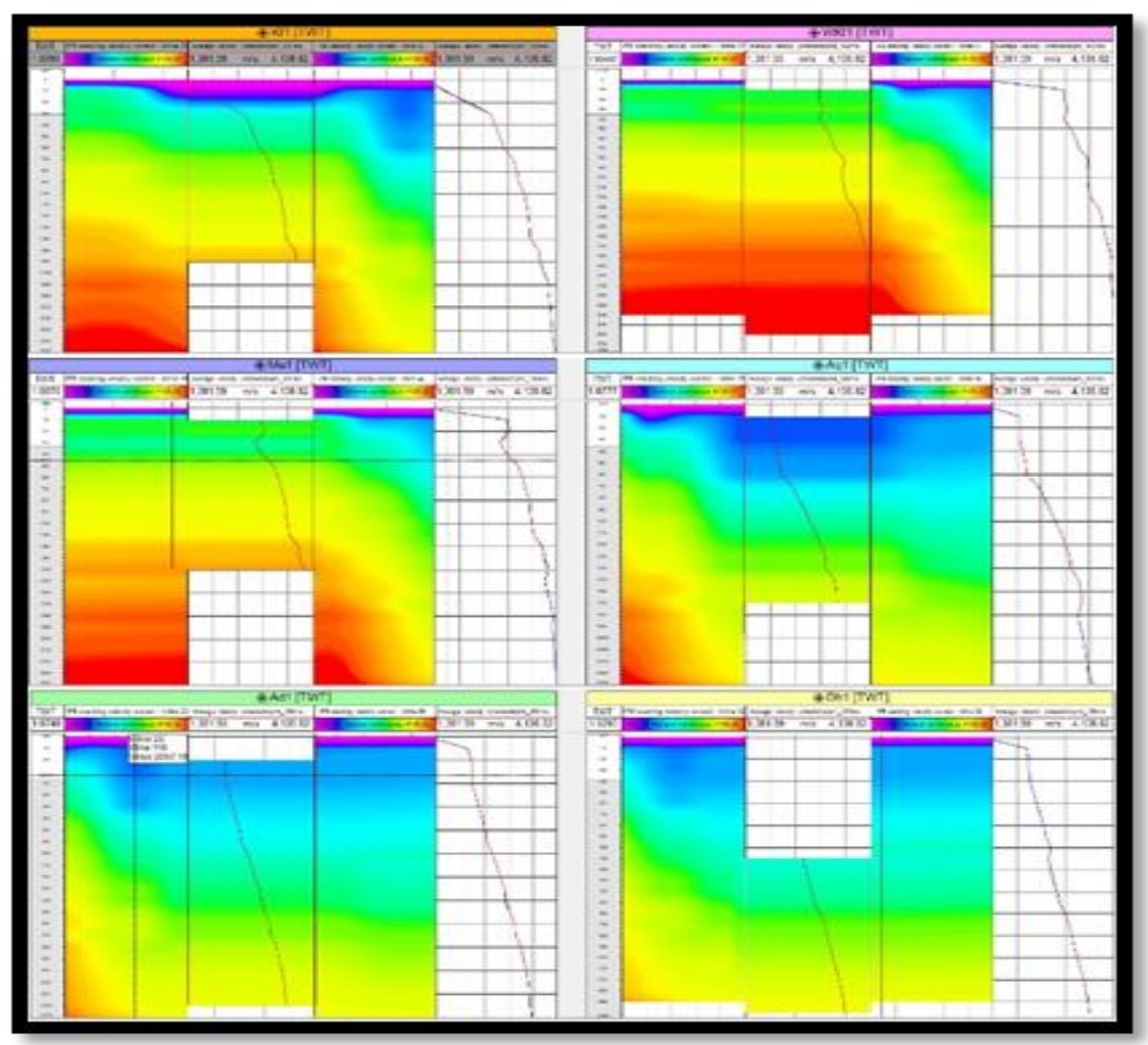

Figure 11- The well section window for QC to the resulted IPB velocity corrected from the QC inversion of 3D grid seismic stacking seismic inversion with wells. 


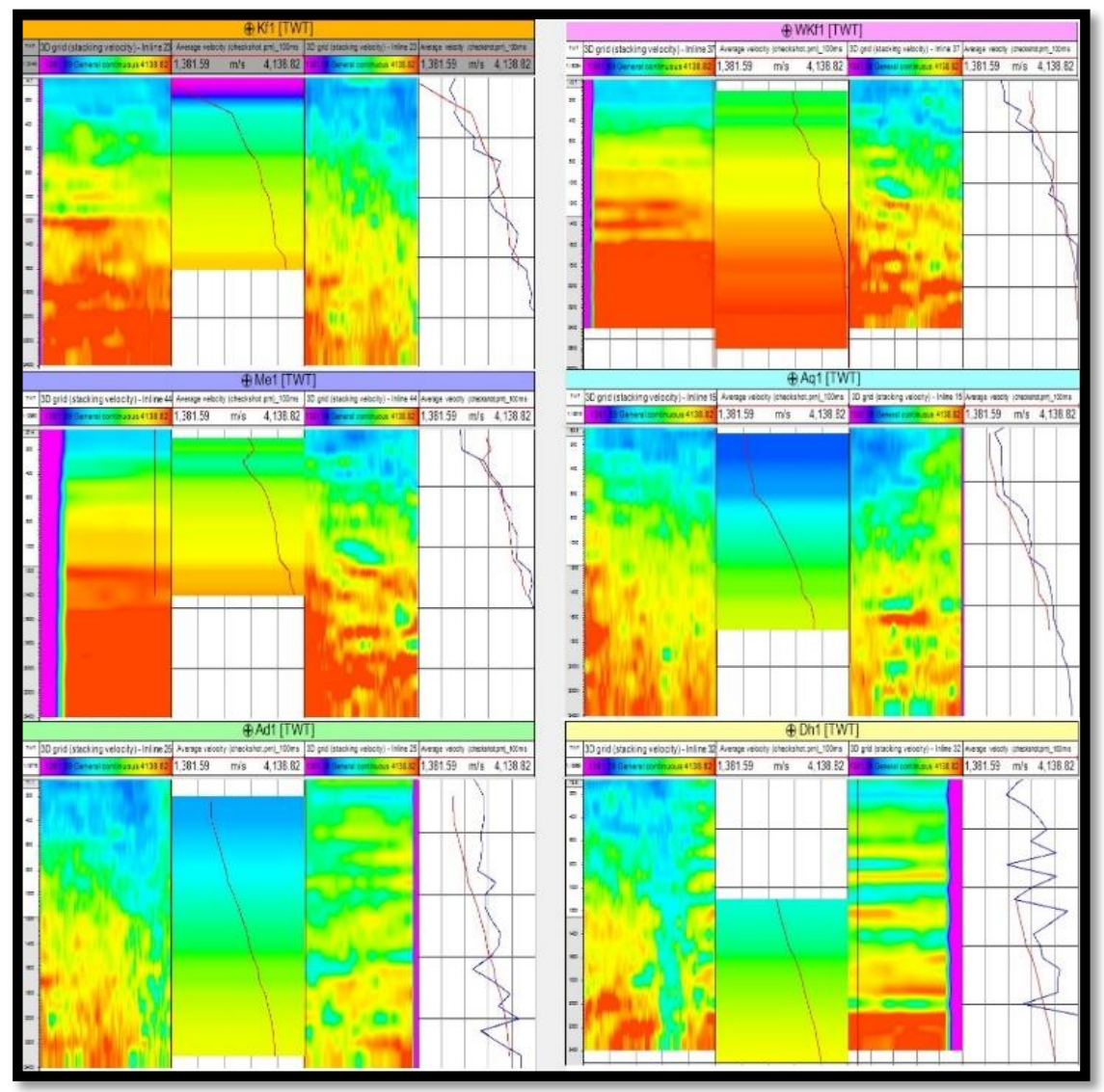

Figure 12- The well section window for the QC inversion of the 3D grid seismic stacking velocity (non-corrected) cube and logs of average velocity of check-shot and wells.

The new IPB velocities of the corrected 3D grid seismic cube were converted to the time modeling and differences with the non-corrected velocity were compared, as shown in Figure- 6 . The new model was drawn in the 3D window. This time model is different from that of the other velocities (stacking, average), because the velocity of the IPB spreads regionally and is equalized to the geological structure of the study area. The time model cannot be interpreted until being converted to depth (Figure- 13).

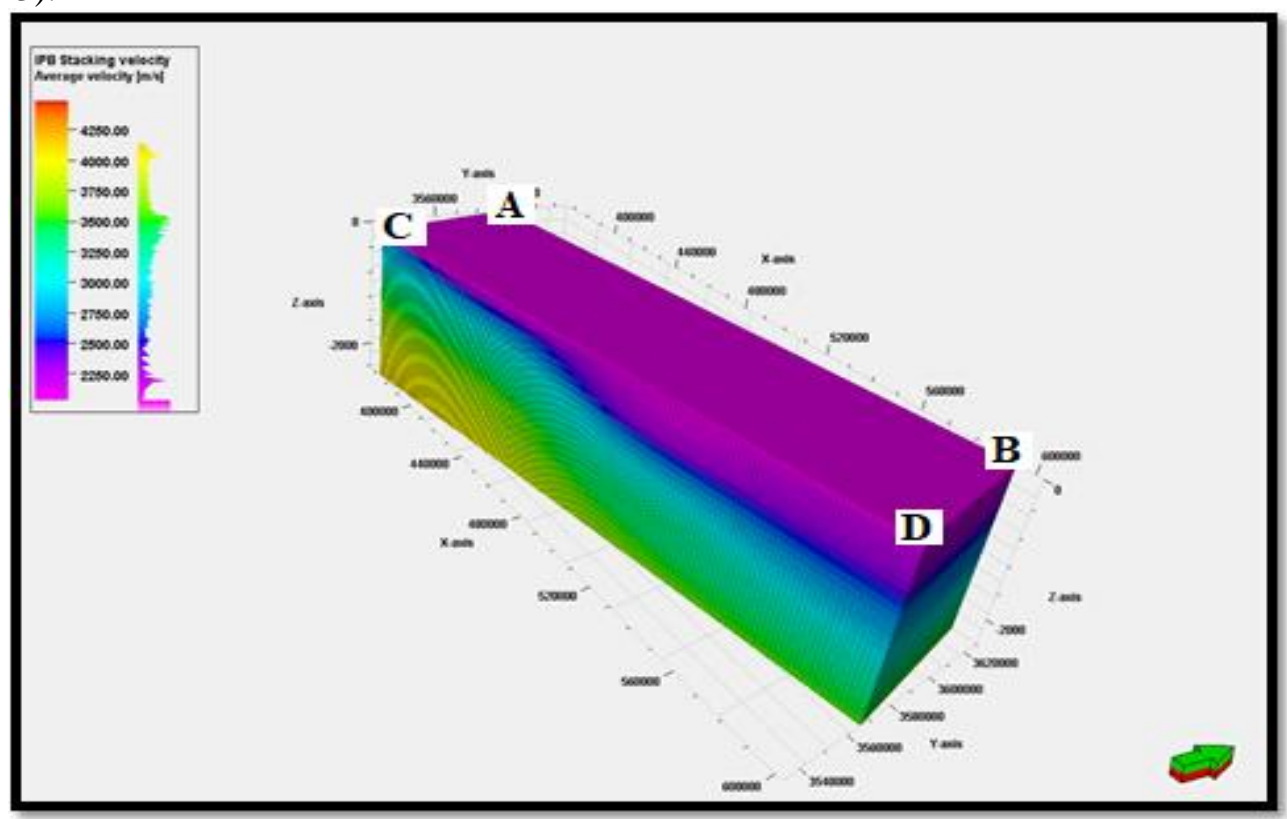

Figure 13- The IPB stacking velocity corrected in time model. 


\section{The velocity model generation}

To convert the time model map into a depth model map, the velocity model is needed.

The purpose of the application of this model is to create a new relationship between time and depth, called TDR (time-depth relation). The new model is generated to make a comparison between time and depth domains, as demonstrated in Figure-14. The velocity is shown to be increased on the left side and decreased on the right side, which is related to the locations of Salman uplift on the left side and the Mesopotamian on the right side. Then we proved the locations of the boundary that separates the stable and unstable shelves and compared the model with the non-corrected model (Figure-15). The matching error between the true velocity of wells and the velocity obtained from this model well is shown in Figure-16.

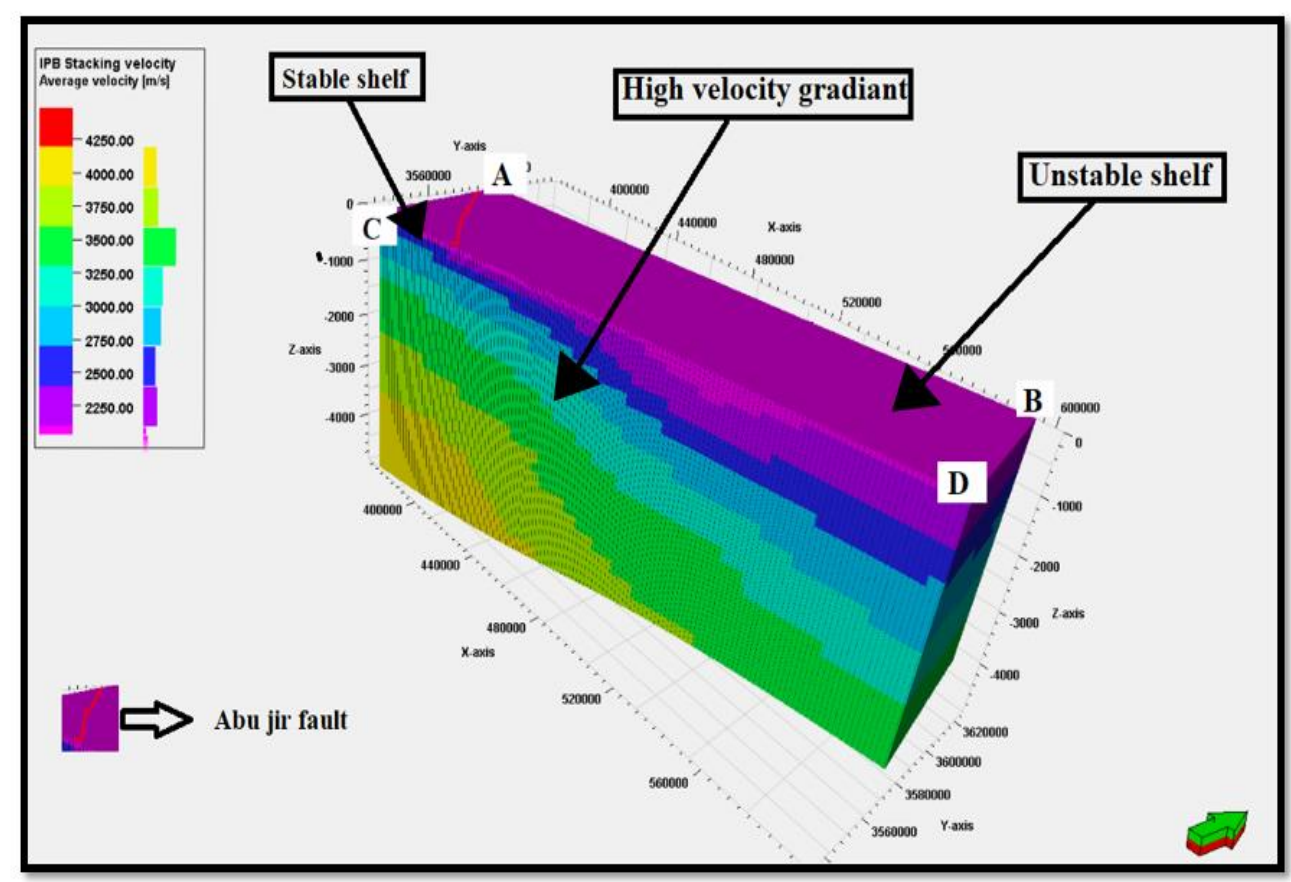

Figure 14- The depth model of IPB corrected velocity.

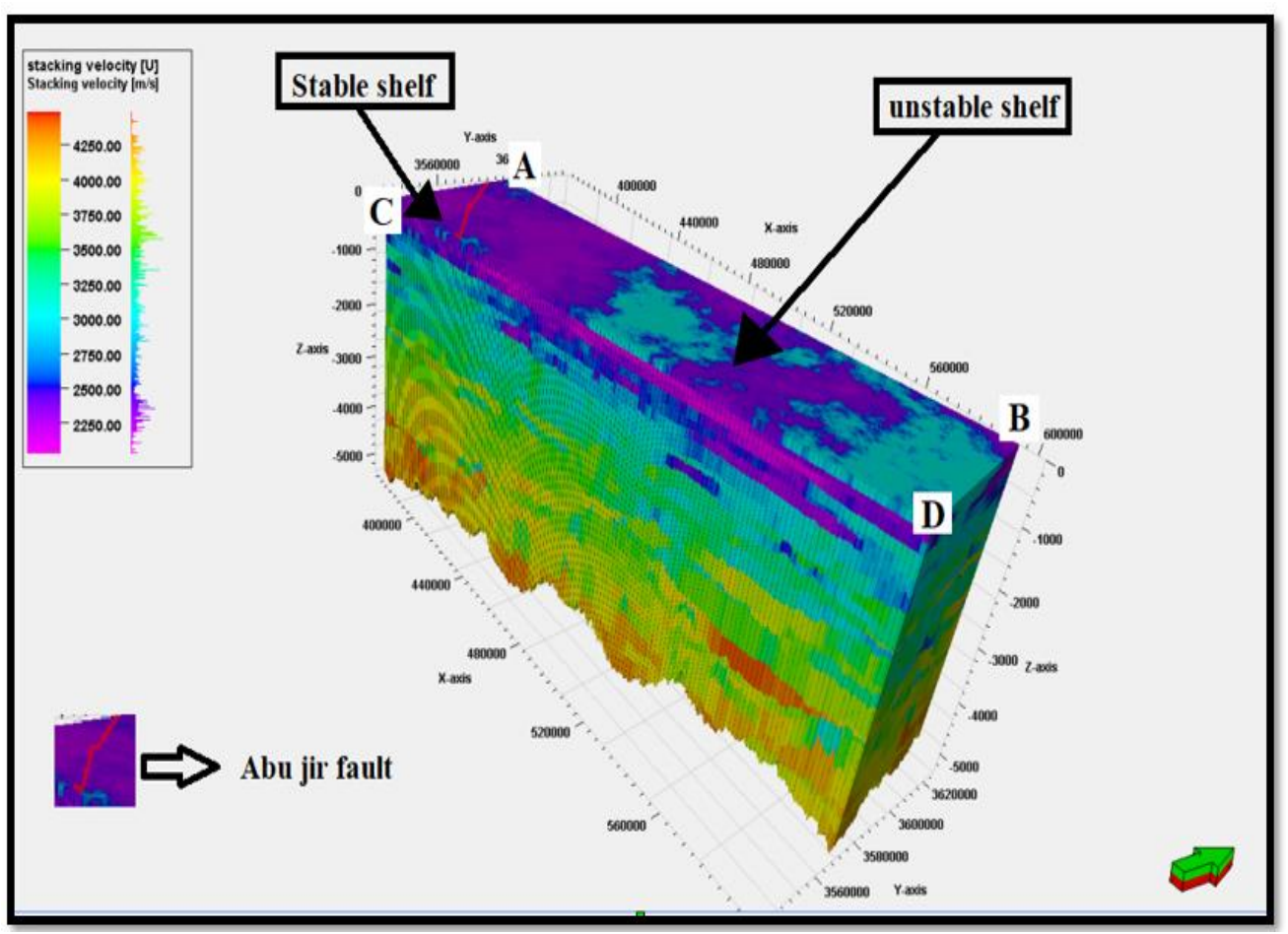

Figure 15- The depth model of stacking non-corrected velocity. 


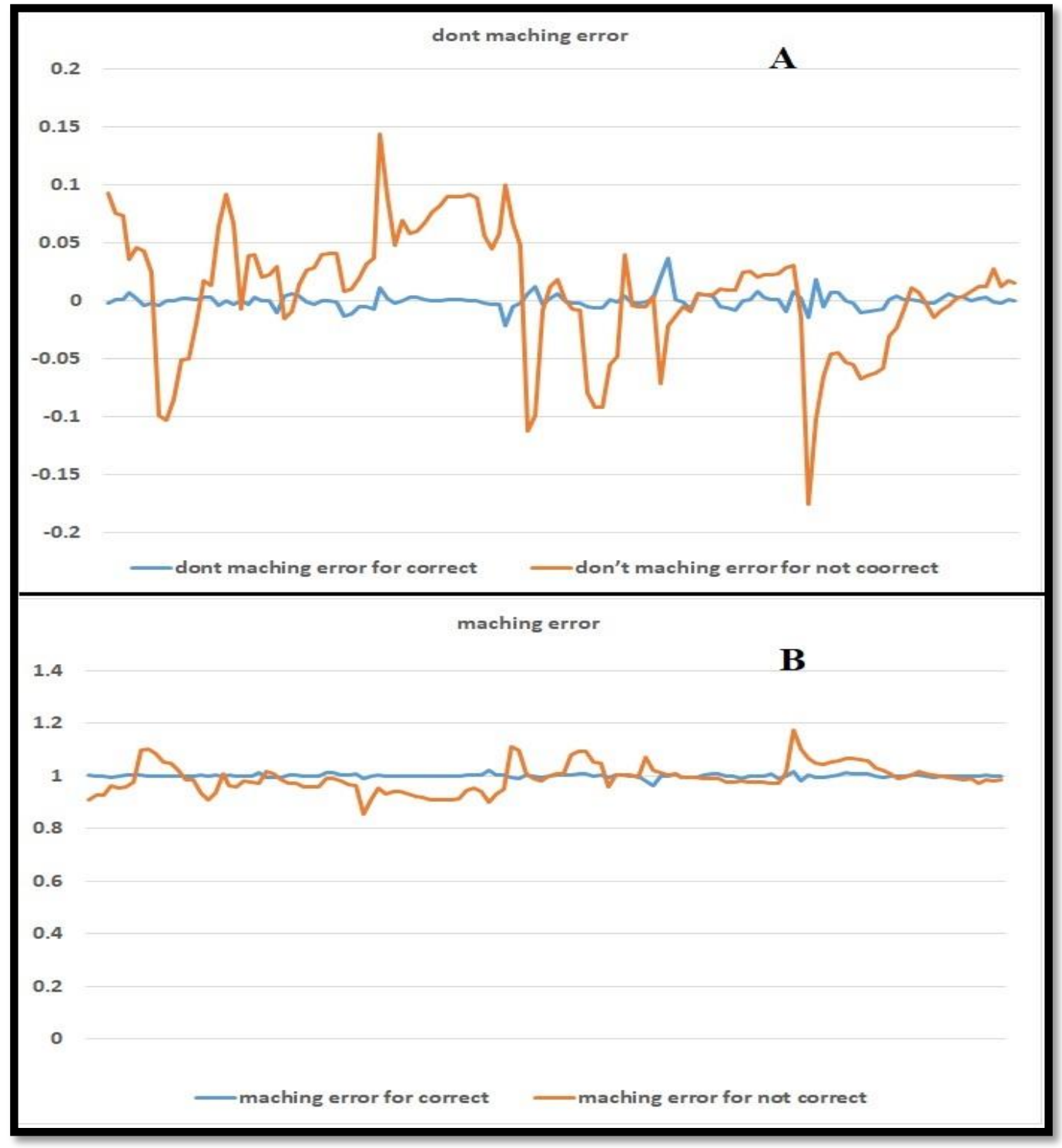

Figure 16- (A) The non-matching error between corrected and non-corrected velocity, (B) The matching error between the corrected and non- corrected velocity.

\section{Conclusions}

The obtained corrected model of the velocity shows smooth and clear distribution of velocity and improves the seismic interpretation, compared to the non-corrected stacking velocity in which the velocity is randomly spread.

The depth model indicates a high velocity at the western side of the study area at Salman tectonic zone and the velocity gradually decreases towards the east at the Mesopotamian tectonic zone.

The western side of the study area, which is considered as a part of the stable shelf, is characterized in the depth model by low thickness and high velocity layers. While the eastern side, which is a part of the Mesopotamian tectonic zone, is characterized by relatively high thickness and 23 low velocity layers.

Abu Jir fault, which separates the stable from the unstable shelves, is located at the extreme western part of the study area.

5- The area which has the relatively high gradient in velocity from the west toward the east represents the western side of the Mesopotamian basin. 


\section{References}

1. Gadallah, M. R., and Fisher, R. 2009. Exploration Geophysics, Springer-Verlag Berlain Heidelberg, $262 \mathrm{p}$.

2. McQuillin, R., Bacon, M., \& Barclay, W. 1984. An introduction to seismic InterpretationReflection seismics in petroleum exploration.

3. Maerck;in N., Ritzmann O., Faleide N., Bungum H., Mooney W. , and Detweiler S. 2005. Construction and testing of a 3D seismic velocity model in the greater Barents Sea region. EGU General Assembly, European Geosciences Union Conference at Wien, Austria.

4. Dalfsen W., Doornenbal J., Dortland S., and Gunnink J. 2016. A comprehensive seismic velocity model for the Netherlands based on lithostratigraphic layers. Netherlands Journal of Geosciences, 85(4): 277-292.

5. Alsalem A. 2016. 3D seismic depth imaging and velocity model building in anisotropic media: Serri Oil and Gas Field, Saudi Arabia. M Sc. Thesis, University of South Carolina. 67p.

6. Alaminiokuma, G. I., \& Ugbor, C. C. 2010. Analytical velocity model for depth conversion in the subsurface facies of Agbada formation in the Niger Delta, Nigeria. The Pacific Journal of Science and Technology, 11(1): 563-575.

7. Sadooni, F. N., \& Aqrawi, A. A. 2000. Cretaceous sequence stratigraphy and petroleum potential of the Mesopotamian basin, Iraq.

8. Sadooni, F. N. 1993. Stratigraphie Sequence, Microfacies, and Petroleum Prospects of the Yamama Formation, Lower Cretaceous, Southern Iraq. AAPG bulletin, 77(11): 1971-1988.

9. United Nations, 2014. Iraq administered map, Department of field support, Cartographic section, Map No. 3835 Rev. 6

10. Buday, T. and Jassim, S. Z. 1984. Geological map of Iraq 1: 1,000,000 Scale Series, Tectonic map of Iraq, Publication of GEOSURV, Baghdad, sheet No. 2.

11. AL-Banna, A. S., \& Ali, K. K. 2018. The Transition Tectonic Zone Between the Two Parts of the Platform in Iraq: A Review Study. Iraqi Journal of Science, 59(2C):1086-1092.

12. AL-Kadhimi, J. A. M., \& Fattah, A. S. 1994. Bouguer Anomalies map of Iraq, published by Iraqi GEOSURV. Baghdad/Iraq.

13. Jassim, S.Z. and Goff, J.C. 2006. Geology of Iraq. DOLIN, sro, distributed by Geological Society of London.

14. Fouad, S. F. A. 2013. Tectonic Map of Iraq, 1: 1,000,000 Scale Series, Tectonic map of Iraq, Publication of GEOSURV, Baghdad, sheet No. 2.

15. Sissakian, V. K., \& Jab'bar, M. F. A. 2014. Classification of the Alluvial Fans in Iraq. Iraqi Bulletin of Geology and Mining, 10(3): 43-67

16. AL-Banna, A. S., \& Aziz, A. F. 2019. Gravity and Magnetic Interpretation to Study Deep Crustal Structures in Karbala and Surrounding Areas-Central Iraq. Iraqi journal of Science, 536-544. 